\title{
INDIRECT SUCCESS? THE IMPACT AND USE OF THE ICRMW IN OTHER UN FORA
}

Stefanie Grant and Beth Lyon*

\section{Introduction}

The UN Convention on the Protection of the Rights of All Migrant Workers and Members of their Families (Migrant Workers Convention, the Convention or ICRMW) broke ground in international law by articulating baseline treatment for all migrants. But as the Convention approaches its 30 year mark with only 51 state parties, it is an outlier amongst the 'core' UN human rights instruments. ' This low level of ratification reflects difficulty in shifting the perception by many sovereign

* The authors are grateful to Giulia Barbone and Azadeh Erfani for their research assistance, and to Jane Connor, Pia Oberoi, Bradford Smith, and the reviewers, including Alan Desmond, for their insights and advice; any errors are the authors' own. The chapter was completed prior to the intergovernmental consultations and negotiations, set in train by the New York Declaration of 19 September 2016, which are due to culminate in the adoption of a Global Compact on Migration in 2018.

1 The UN has adopted the term 'core' to describe these ten treaties. See United Nations Human Rights Office of the High Commissioner 'The Core International Human Rights Instruments and their monitoring bodies' http://www.ohchr.org/EN/ ProfessionalInterest/Pages/CoreInstruments.aspx (accessed 29 August 2016). The ten treaties are: (1) International Convention on the Elimination of all forms of Racial Discrimination (CERD), Mar. 7, 1966, 660 UNTS 195 (entered into force 4 January 1969); (2) International Covenant on Civil and Political Rights (CCPR), Dec. 16, 1966, 999 UNTS 171 (entered into force 23 March 1976); (3) International Covenant on Economic, Social and Cultural Rights (CESCR), Dec. 16, 1966, 993 UNTS 3 (entered into force 3 January 1976); (4) Convention on the Elimination of All Forms of Discrimination against Women (CEDAW), Dec. 18, 1979, 1249 UNTS 13 (entered into force 3 September 1981); (5) Convention Against Torture and Other Cruel, Inhuman or Degrading Treatment or Punishment (CAT), Dec. 10, 1984, 1465 UNTS 85 (entered into force 26 June 1987); (6) Convention on the Rights of the Child (CRC), Nov. 20, 1989, 1577 UNTS 3 (entered into force 2 September 1990); (7) International Convention on the Protection of the Rights of All Migrant Workers and Members of Their Families (ICRMW), Dec. 18, 1990, 2220 UNTS 3 (entered into force 1 July 2003); (8) Convention on the Rights of Persons with Disabilities (CRPD), Dec. 13, 2006, 2515 UNTS 3 (entered into force 3 May 2008); and (9) International Convention for the Protection of All Persons from Enforced Disappearance (CPED), Dec. 20, 2006, 2716 UNTS 3 (entered into force 23 December 2010); and (10) Optional Protocol of the Convention against Torture (OP-CAT), Dec. 18, 2002, 2375 UNTS 237 (entered into force 22 June 2006). 
states of migrants as intruders/supplicants to one of migrants as rightsbearing subjects. The struggle to establish the ICRMW takes place in the context of vibrant activity around the growing number of international and regional human rights treaties focused on other vulnerable groups ${ }^{2}$ and human rights concerns. In the United Nations alone, the High Commissioner for Human Rights, expert committees, individual experts, and other bodies work together with governments and civil society to monitor human rights treaty implementation and undertake related humanitarian work. ${ }^{3}$ The objective of this chapter is to provide an account of how some of these UN processes are interacting with the Convention. ${ }^{4}$ The chapter does not provide a full account of how UN processes have handled migration issues, but rather addresses the more technical issue of the integration of the ICRMW itself into the work of other bodies.

The chapter divides its analysis of the interactions between selected UN processes and the Migrant Workers Convention into two categories, substantive and institutional. In each category, the discussion includes both standing fora and special mechanisms of the UN. The standing fora examined are the UN Human Rights Council, and the treaty bodies for the nine other principal human rights treaties. We examine special procedures that involve an overlap with the Migrant Workers Convention, including the Special Rapporteurs on the Human Rights of Migrants and on Trafficking in Persons, especially women and children. We also consider some recent global governmental processes around migration outside the UN. A limited time frame had to be selected: the focus of the analysis is recent interactions (2013-2015), a scope that allowed for a closer survey of the substantial volume of work produced by these mechanisms during the period in question.

Since 1990, UN human rights treaty bodies have interpreted and reinterpreted their specific mandates to include all migrants. ${ }^{5}$ This has led

2 The phrases 'vulnerable people', 'vulnerable populations', and 'vulnerable communities' are common in international human rights policy. Indeed, so frequent is the use of the term 'vulnerable' that in our view it has become a term of art. Emerging criticism of the term raises the concern that using 'vulnerable' as an adjective describing subordinated people may invoke victimhood and therefore essentialises and disempowers the most deserving subjects of human rights. In this chapter, we continue to use these phrases despite these concerns, as we feel that at this juncture there is no discussion, let alone consensus, on a replacement term. In a number of instances where we use the term, it is a direct quotation.

3 For example, the UN Human Rights Council, the ten Committees monitoring the ten core human rights instruments, the International Labour Organization, agencies with combined humanitarian and protection mandates such as the UNICEF and the Office of the High Commissioner for Refugees, and the 'special procedures' of the Human Rights Council, through which experts promote human rights, currently through 39 thematic and 14 country-focused mandates. See Annual Report of the United Nations High Commissioner for Human Rights and Reports of the Office of the High Commissioner and the Secretary-General Human Rights Bodies and Mechanisms, HRC Council (29 January 2015), UN Doc A/HRC/28/41 (2015) 3, noting that as of January 2015, there were 77 mandate-holders.

4 For the purposes of this chapter, we see impact as supportive and normative references to the Convention. 
to an increase in the inclusion of migrants' rights in the work of all the treaty bodies. But it has also led to over-lapping jurisdictions, the risk of diverging interpretations, and of different treaty bodies acting independently to monitor obligations relating to migrants' rights in their specific treaties.

The need for more co-ordination between treaty bodies is recognised as a problem facing the UN treaty body system as a whole. ${ }^{6}$ One consequence has been that even when specialised migration issues arise in states' reports that are addressed by the Convention, generally it is not invoked by treaty bodies; they do not typically cite to the Convention even regarding issues the Committee on Migrant Workers (CMW) has addressed in its own Concluding Observations. This trend is part of a broader pattern of lack of cross-referencing by the treaty bodies. In response, the CMW has advised that:

[A] State's obligation under the Convention must be read with respect to the core human rights treaties and other relevant international instruments to which it is a party. Although separate and freestanding, these treaties are complementary and mutually reinforcing.

A number of UN human rights experts and mechanisms do make reference to the Migrant Workers Convention, as has the High Commissioner for Human Rights. For example, in his 2013 report, Special Rapporteur on the human rights of migrants, François Crépeau noted that:

Only 46 States have ratified the International Convention on the Protection of the Rights of All Migrant Workers and Members of Their Families. However, it mainly restates rights that already follow from other treaties. All States have ratified at least one of the other core international human rights treaties and, owing to the non-discrimination principle, are thus obliged to respect the human rights of migrants, including those in an irregular situation. ${ }^{8}$

See generally S Grant 'Migrants' rights within the UN system: The first 60 years' in MD Dembour \& T Kelly (eds) Are human rights for migrants? (2011).

6 The problem is not specific to the UN system. 'Overlapping, concurrent or competing claims to competence are common in the case of ... international expert bodies ... because each ... is the product of a treaty arrangement that defines its range of responsibilities and each is therefore independent of the other' Y Tyagi The UN Human Rights Committee: Practice and procedure (2011) 758. See Concept Paper on the High Commissioner's Proposal for a Unified Standing Treaty Body, Report by the Secretariat, International Human Rights Instruments (22 March 2006), UN Doc HRI/ MC/2006/2 (2006) para 23; E Tistounet 'The problem of overlapping among different treaty bodies' in P Alstn \& J Crawford (eds) The future of UN human rights treaty monitoring (2000) 383-401.

7 General Comment 2: On The Rights of Migrant Workers in an Irregular Situation and Members of their Families, CMW Committee (28 August 2013), UN Doc CMW/C/ GC/2 (2013) para 7.

8 Report of the Special Rapporteur on the human rights of migrants, François Crépeau, GA (7 August 2013), UN Doc A/68/283 (2013) para 29 (Crépeau Report). 
Although this statement may have seemed to dismiss the Convention, in the same report the Special Rapporteur characterised the Convention as a 'crucial measure in relation to the human rights of migrants'?

In addition, the UN human rights mechanisms are virtually uniform in making consistent calls for ratification of the ICRMW. But in governmentdriven fora such as the Universal Periodic Review (UPR) and in the nonUN Global Forum on Migration and Development, ${ }^{10}$ support for ratification is sharply divided between proponent states in the Global South and opponents or sceptics in the Global North.

\section{Substantive interaction: Overlapping protection and calls for ratification}

We define substantive interaction as UN human rights monitoring bodies citing the Convention where relevant, either through invoking a substantive Convention provision when this protection overlaps with their own treaties, or by encouraging ratification of the Convention. The following analysis first describes areas of overlapping protection between the Convention and the other human rights treaties, reporting on the level of citation to the Convention in these instances and highlighting missed opportunities to use the Convention to underscore recommendations. We then track the same treaty bodies' calls for ratification.

As compared with the UN's nine other principal human rights treaties, one of the unique features of the ICRMW is that it combines very specific provisions to protect a particular population - documented migrant workers - with general provisions on both documented and more vulnerable undocumented migrants, and on categories of rights, that overlap with other human rights treaties. For example, Part III of the Convention, entitled Human Rights of All Migrant Workers and Members of their Families, contains 24 provisions that set forth protections which are well established in other treaties, ranging from freedom of conscience, liberty and security and protection from torture, to the right to leave and return to one's own country and the right to respect for one's cultural identity. Meanwhile, Part IV sets out additional rights which protect 'Migrant Workers and Members of their Families who are Documented or in a Regular Situation', such as equality of treatment with nationals in the matter of access to vocational services and housing.

92013 Crépeau Report (n 8 above) para 39.

10 These mechanisms differ in that the UPR is an intergovernmental review process of human rights issues within the Human Rights Council and the UN Global Forum on Migration and Development is an informal intergovernmental process without clear institutional footing, but we link them here because the normative statements of each body are shaped and limited by individual governments. 
The historical reason for the overlap in Part III is that the delegates who drafted the treaty were divided over whether to accord rights to irregular or undocumented migrant workers. ${ }^{11}$ The compromise they struck, after years of negotiations, was to devote 35 articles of the treaty to a near-full spectrum of fundamental human rights for all migrant workers and family members, including those lacking regular status, while giving additional protections for those with regular status. The 35 articles are strikingly similar to the provisions of the International Covenant on Civil and Political Rights (ICCPR). At the time it was drafted, these articles were filling a gap in the application of existing protections: some treaties had been understood to exclude irregular migrants - 'non citizens' - from specific provisions. ${ }^{12}$

Between 1990 and 2015, the UN, through its refugee agency, UNHCR, continued to develop the existing international refugee protection regime with new interpretations of refugee law to apply through domestic refugee law and policy. ${ }^{13}$ In the same period, although the UN has no agency with a protection mandate for migrants, ${ }^{14}$ it also - through the Commission on Human Rights and the Human Rights Council began to give attention to migration as a human rights issue. However, some UN member states were unwilling to accept even the extant migrant rights treaties, namely the ILO Conventions and the ICRMW. ${ }^{15}$

11 See Office of the United Nations High Comissioner for Human Rights 'Travaux Préparatoires: Rights of All Migrant Workers (Part III of the Convention)' http:// www2.ohchr.org/english/issues/migration/taskforce/docs/draftinghistoryrev1.doc (accesed 7 September 2016) 1-2; De Guchteneire et al (eds) Migration and human rights: The United Nations Convention on Migrant Workers' Rights (2008).

12 See CERD (n 1 above) art 1(2). In 1980, a study prepared for the Sub Commission on the Prevention of Discrimination and Protection of Minorities concluded that ' $(t)$ he wording of international instruments as they relate to aliens is unclear and imprecise, "nationality" not being included in the non discrimination clauses'. The application of the provisions of international instruments to aliens was 'unclear and uncertain'; existing means of implementation were 'inadequate'. See International Provisions Protecting the Human Rights of Non-Citizens, Baroness Elles (August 1980), UN Doc E/CN.4/Sub.2/392/Rev.1 (1980) para 366 (30 \& 20). The Inter Governmental Working Group of Experts characterised international human rights law for the protection of migrants' rights as 'dispersive and fragmentary'. See Working Group of Intergovernmental Experts on Human Rights of Migrants, CHR (9 March 1999), UN Doc E/CN.4/1999/80 (1999) para 103.

13 See, eg, United Nations High Commissioner for Refugees, Guidelines on International Protection No 9: Claims to Refugee Status based on Sexual Orientation and/or Gender Identity within the context of Article 1A(2) of the 1951 Convention and/or its 1967 Protocol relating to the Status of Refugees, UNHCR (23 October 2012), UN Doc HCR/GIP/12/09 (2012).

14 In July 2016, the International Organisation for Migration became a 'Related Organization' to the UN: IOM 'IOM Becomes a Related Organization to the UN' 25 July 2016 http://www.iom.int/news/iom-becomes-related-organization-un (accessed 13 October 2016). 
Meanwhile, the human rights situation of migrants worsened as numbers rose in a globalising world where jobs could move freely, but workers could not legally cross borders, leading to large irregular movements. In 2004, the ILO reported that:

[F]or an unacceptably large proportion of migrants, working conditions are abusive and exploitative, and may be characterized by forced labour, low wages, poor working environment, a virtual absence of social protection, the denial of freedom of association and union rights, discrimination and xenophobia, as well as social exclusion, all of which rob workers of the potential benefits of working in another country. The development of labour institutions for the protection of migrant workers has lagged behind the growth of migration. ${ }^{16}$

Governments increasingly treated migration as an enforcement problem instead of developing meaningful low wage visa regimes to normalise and regulate migration flows and protect labour rights. ${ }^{17}$ During these 25 years, world attention focused on sex-and-labour-trafficking, smuggling, and child migration, creating a discourse of migrant-as-victim/survivor that generally failed to gain policy purchase in terms of rights protection. Instead, and especially after 2001, the enforcement-focused discourse of migrant-as-criminal, and even as terrorist, dominated the international policy agenda, exacerbating the humanitarian plight of migrants. ${ }^{18}$

As awareness grew both of the importance of migration as a transnational reality, and of human rights abuses against migrants, the UN took those limited steps that were politically possible on an issue on which states were reluctant - in some cases unwilling - to accept any multilateral intrusion into national sovereignty; most notable is the General Assembly's High-Level Dialogue on International Migration and Development (see section 2.3 below). In 2003, after proposals for a UNmigration conference failed to find support amongst member states - fewer than half even replied to a questionnaire soliciting their views - the then Secretary-General Kofi Annan encouraged states to address the issue of

15 The ILO Conventions dedicated to migrants continued at low ratification rates during this period. See ILO 'Migration for Employment Convention (Revised), 1949 (No 97)' http://www.ilo.org/dyn/normlex/en/f?p=1000:11300:0::NO:11300:P11300_INST RUMENT_ID:312242 (accessed 14 September 2016) (38 state parties as of 1990); ILO 'Migrant Workers (Supplementary Provisions) Convention, 1975 (No 143)' http:// www.ilo.org/dyn/normlex/en/f?p=1000:11300:0::NO:11300:P11300_INSTRUMEN T_ID:312288 (accessed 14 September 2016) (14 state parties as of 1990). For an overview of the protection of migrant workers' rights under ILO and UN treaties, see International Labour Office Towards a fair deal for migrant workers in the global economy (2004) chap 4.

16 HILO (n 15 above) para 126

17 See, eg, F Crépeau 'Foreword' in L Berg (ed) Migrant rights at work: Law's precariousness at the intersection of immigration and labour (2016) xiii-xvi (2016) (noting border control obsessions and populist-nationalist rants).

18 On forced migration and refugees, see generally E Fiddian-Quasmiyeh et al The Oxford handbook of refugee and forced migration studies (2014). Also A Betts Global migration governance (2011). See, too, Report of the Special Rapporteur on the human rights of migrants, GA (20 July 2016), UN Doc A/71/40767 (2016) paras 8-18. 
international migration substantively, but outside the UN, through a Global Commission on International Migration. ${ }^{19}$ Annan invited the Commission to set a 'strong ethical compass' for policy makers, and to help 'win broad acceptance for a normative framework that has human rights at its heart'. He described the ICRMW as 'the bill of rights for migrant workers and their families in their new home countries' and called for its ratification. ${ }^{20}$ Although the Commission's report recommended strengthening UN capacity for the protection of human rights, it did not follow Kofi Annan's lead in recommending that states ratify the ICRMW. ${ }^{21}$

At the time when the Convention was adopted by the General Assembly in 1990, there was considerable uncertainty even amongst legal experts as to the degree to which human rights, although universal in principle, protected non-nationals, and particularly non-nationals who had no legal status, in practice. ${ }^{22}$ In one of the core treaties it even appeared that discrimination on the basis of nationality was allowed. ${ }^{23}$ Faced with this apparent contradiction to universality, and with the assistance of an expert report to the Human Rights Commission, ${ }^{24}$ treaty bodies asked themselves whether, and how far, their individual mandates applied to migrants. Between 2004 and 2009, they confirmed that states are generally bound by the treaties to protect all migrants, regardless of legal status. ${ }^{25}$

The Commission on Human Rights also gave increased attention to migrant protection through the creation of special procedures for which the co-operation of states was required to operate effectively, but not their

19 Report of the Global Commission on International Migration 'Migration in an interconnected world: New directions for action' (Geneva, 2005). See K Newland 'Migration's unrealised potential: The Report of the Global Commission on International Migration' (1 November 2005) http://www.migrationpolicy.org/article/ migrations-unrealized-potential-report-global-commission-international-migration (accessed 13 October 2016); S Grant "GCIM: Defining an "ethical compass" for international migration policy' (2006) 44 International Migration 13.

20 See UN Meeting Coverage and Press Releases 'Secretary-General, in Lecture on international flows of humanity, says human rights must be at the heart of migration policies' (21 November 2003), UN Doc SG/SM/9027 (2003). Kofi Annan, speaking at the launch of the Global Commission on International Migration: UN Information Service, 'Win-win outcomes possible if approach to migration is rational, compassionate, Secretary-General Annan tells New Global Commission' (10 December 2003), UN Doc SG/SM/9064 SOC/4632 (2003).

21 Former Secretary-General Ban Ki Moon consistently urged states to ratify the ICRMW; see eg, Report of the Secretary General 'Promotion and protection of human rights, including ways and means to promote the human rights of migrants' GA (7 August 2014), UN Doc A/69/277 (2014) paras 11 and 79(a).

22 See generally S Grant 'Migrants' rights within the UN system: The first 60 years' in MD Dembour \& T Kelly (eds) Are human rights for migrants? (2011).

23 CERD (n 1 above) art 1(2): 'This Convention shall not apply to distinctions, exclusions, restrictions or preferences ... between citizens and non citizens'.

24 See D Weissbrodt The human rights of non citizens (2008) 37.

25 The texts adopted by the Treaty Bodies are cited below. Also, see, for example, M Satterthwaite 'Crossing borders, claiming rights: Using human rights law to empower women migrant workers' (2005) 8 Yale Human Rights and Development Law Journal 1. 
approval of the experts' findings. The Commission established the Special Rapporteurship on the Human Rights of Migrants in 1999 and the Special Rapporteurship on Trafficking in persons, especially women and children, in 2004. ${ }^{26}$ Beginning in 2006, the UN's new Human Rights Council with its innovative UPR process, created an important space for reviewing UN members' compliance with human rights law, providing a new opportunity to monitor migrants' rights.

As each of these processes moved forward, those involved had to determine whether and how to interact with the CMW. As each subsequent attempt to convince wealthy, destination states to ratify the Convention failed, some officials and advocates increasingly feared it was a legal and political dead-end, despite fifty years of relatively steady human rights treaty promulgation, ratification and monitoring of vulnerable populations in which migrants were represented, including as women and children. As the following description reflects, the weight and institutional momentum of that history kept explicit pessimism about the Convention's prospects largely out of official statements. Most public statements by inter-governmental agencies express nothing but support for the Convention.

\subsection{Treaty bodies}

\subsubsection{Human Rights Committee}

The ICCPR established the Human Rights Committee (HRC) in 1976. The ICCPR now has 169 state parties, 116 of which have accepted the Committee's jurisdiction to consider individual complaints. One of the oldest of the principal human rights treaties, the ICCPR was drafted to make enforceable the civil and political rights contained in the Universal Declaration of Human Rights. As originally drafted, the ICCPR contains language excluding irregular migrants from article 12(1) ('liberty of movement and freedom to choose [one's] residence') ${ }^{27}$ The Convention also omits nationality - as opposed to 'national origin' - from its article 2(1) enumerated list of protected categories. However, in subsequent pronouncements, the Committee extended Covenant protections to irregular migrants. In its General Comment 15 (1986) on the position of aliens under the Covenant, the Committee clarified that all but two

26 The mandate of the Special Rapporteur on the human rights of migrants was created pursuant to Resolution 1999/44 of the Commission on Human Rights, while the mandate of the special Rapporteur on trafficking in persons, especially women and children was created pursuant to Resolution 2004/110.

27 The ICCPR limited those rights to those 'lawfully within the territory of a State'. 
provisions of the Covenant must be guaranteed without discrimination as between non-nationals and citizens. ${ }^{28}$ In 2004 , it was more specific: the right must be available to 'all individuals, regardless of nationality... such as migrant workers ... who might find themselves in the territory or subject to the jurisdiction' of a state party. ${ }^{29}$

In the two-year period under consideration, the Committee paid significant attention to the situation of migrants. Amongst its concerns were the failure to respect non-refoulement (Malta, Peru, and Angola), ${ }^{30}$ the excessive detention or ill-treatment of detainees (Angola, Japan, Latvia, Malta, and the United States), ${ }^{31}$ failure to guarantee legal representation for unaccompanied children (Malta), 32 ill-treatment of migrants in deportation (Japan and Angola), ${ }^{33}$ confiscation of travel documents (Chile), ${ }^{34}$ the need to increase access to health care (United States), ${ }^{35}$ the need to train officials to screen for trafficking situations (United States), ${ }^{36}$ the need to adopt affordable measures to hold employers to account for domestic worker abuse (Hong Kong and Macao, China), the need for Hong Kong, China to repeal a rule requiring departure within two weeks after job termination, 37 the need for Korea to guarantee the Covenant rights to migrants, ${ }^{38}$ the need for Paraguay to provide protection

28 Article 25 limits the rights to political participation, public service and the vote to citizens, and art 13 provides due process rights to aliens in expulsion. See General Comment 15 on the position of aliens under the Covenant (Twenty-seventh session, 1986), Compilation of General Comments and General Recommendations adopted by Human Rights Treaty Bodies, HRC (1994) UN Doc HRI/GEN/1/Rev.1 (1994) 18, paras $2 \& 6$.

29 General Comment 31 on the nature of the general legal obligation on state parties to the Covenant, CCPR Committee (29 March 2004), UN Doc CCPR/C/21/Rev.1/ Add.13 (2004) 10 .

30 See Concluding Observations on the Second Periodic Report of Malta, CCPR Committee (21 November 2014), UN Doc CCPR/C/MLT/CO/2 (2014). Concluding Observations on the Fifth Periodic Report of Peru, CCPR Committee (29 April 2013), UN Doc CCPR/C/PER/CO/5 (2013); Concluding Observations on the Initial Report of Angola, CCPR Committee (29 April 2013), UN Doc CCPR/C/AGO/CO/ 1 (2013).

31 As above; Concluding Observations on the Sixth Periodic Report of Japan, CCPR Committee (20 August 2014), UN Doc CCPR/C/JPN/CO/6 (2014); Concluding Observations on the Third Periodic Report of Latvia, CCPR Committee (11 April 2014), UN Doc CCPR/C/LVA/CO/3 (2014); Concluding Observations on the Fourth Periodic Report of the United States of America, CCPR Committee (23 April 2014), UN Doc CCPR/C/USA/CO/4 (2014).

32 As above.

33 See n 31 and n 32 above.

34 See Concluding Observations on the Sixth Periodic Report of Chile, CCPR Committee (13 August 2014), UN Doc CCPR/C/CHL/CO/6 (2014).

35 n 31 above.

36 As above.

37 See Concluding Observations on the Third Periodic Report of Hong Kong, China, CCPR Committee (29 April 2013), UN Doc CCPR/C/CHN-HKG/CO/3 (2013); For Macao, China, see Concluding Observations on the Initial Report of Macao, China, CCPR Committee (29 April 2013), UN Doc CCPR/C/CHN-MAC/CO/1 (2013).

38 See Concluding Observations on the Initial Report of the Republic of Korea, CRPD Committee (29 October 2014), UN Doc CRPD/C/KOR/CO/1 (2014). 
and rehabilitation to trafficking survivors, ${ }^{39}$ and the need to improve language education for ethnic minorities (Hong Kong, China). ${ }^{40}$

Of the countries whose migrant rights record it considered, two (Paraguay and Peru) are parties to the ICRMW. Given those ratifications, citation to the ICRMW would here have been appropriate, but would have run counter to the HRC's general practice. As a general matter, the HRC does not cite to other treaties or treaty body jurisprudence. ${ }^{41}$ In none of the migrant-related Concluding Observations listed above did the HRC cite to another treaty. Nor does the HRC generally cite to any other Committee's jurisprudence. However, when it recommended that Hong Kong, China, provide language education for language minorities, the HRC noted it was 'reinforcing' a CERD recommendation made to the same country. ${ }^{42}$ The HRC might have similarly referenced the findings of the CMW when it recommended that Chile stop confiscating travel documents, as the CMW had made this recommendation to Chile three years before the HRC did so. ${ }^{43}$

\subsubsection{Committee on Economic, Social and Cultural Rights}

Like the ICCPR, the International Covenant on Economic, Social and Cultural Rights (CESCR) was drafted to implement the Universal Declaration of Human Rights, and entered into force in 1976. A hundredand-sixty-five countries have ratified CESCR, of which 22 have accepted the Committee's jurisdiction over individual complaints of breaches of the treaty. Also like the ICCPR, CESCR includes a provision limiting protection for migrants in some circumstances. Article 2(2) contains the Covenant's non-discrimination provision, which instructs member states to respect Covenant rights 'without discrimination of any kind as to race, colour, sex, language, religion, political or other opinion, national or social origin, property, birth or other status', but article 2(3) provides that '[d]eveloping countries ... may determine to what extent they would guarantee the economic rights recognized in the present Covenant to nonnationals'. ${ }^{4}$

Unlike the ICCPR, CESCR had no monitoring body until 1985, when the UN Economic and Social Council created the Committee on Economic, Social and Cultural Rights. The Committee has interpreted the

39 See Concluding Observations on the Third Periodic Report of Paraguay, CCPR Committee (29 April 2013), UN Doc CCPR/C/PRY/CO/3 (2013).

40 n 37 above

41 The Committee monitors implementation of the ICCPR, but has no direct role in the implementation of any other international human rights treaty. See Tyagi (n 6 above) 758.

42 As above.

43 Consideration of Reports submitted by States Parties under art 74 of the Convention, CMW Committee (19 October 2011), UN Doc CMW/C/CHL/CO/1 (2011) 21.

44 CESCR, arts 2(2) and 2(3). 
treaty to extend protection to all migrants, most notably in its 2009 General Comment 20: 'The Covenant rights apply to everyone including nonnationals, such as refugees, asylum-seekers, stateless persons, migrant workers and victims of international trafficking, regardless of legal status and documentation. ${ }^{45}$ As a result of its protection for all migrants, CESCR also sets a higher standard by filling at least two gaps in the ICRMW. Article 12 CESCR contains a right 'to the enjoyment of the highest attainable standard of physical and mental health', while the ICRMW guarantees only 'any medical care that is urgently required for the preservation of their life or the avoidance of irreparable harm to their health'. ${ }^{46}$ Similarly, the Migrant Workers Convention lacks a protection for the right to housing. 47

In other General Comments, the Committee further confirmed CESCR protections for migrants, including the right to protection of cultural identity, ${ }^{48}$ and the right to participate in social security or at the least a refund of contributions. ${ }^{49}$ Notably, in its General Comment 18 on the Right to Work, the Committee cited the Migrant Workers Convention, stating the principle of nondiscrimination as set out in article 2(2) CESCR and in article 7 ICRMW:

[S]hould apply in relation to employment opportunities for migrant workers and their families. In this regard the Committee underlines the need for national plans of action to be devised to respect and promote such principles by all appropriate measures, legislative or otherwise. ${ }^{50}$

In the two years under review, the Committee on ESCR did not make reference to the substantive provisions of the Convention, although it did give detailed consideration to relevant issues. For example, the Committee recommended a number of measures for Tajikistan to improve protection for its expatriate and returnee nationals, as well as their families. ${ }^{51}$ The Committee also raised concerns about access to justice for migrants in

45 General Comment 20 on non-discrimination in economic, social and cultural rights, CESCR Committee (2 July 2009), UN Doc E/C.12/GC/20 (2009) 30.

46 ICRMW (n 1 above) art 28. See also the contribution of Georgopoulou et al to this volume.

47 Cf CESCR (n 1 above) art 11(1).

48 General Comment 21 on the right of everyone to take part in cultural life, CESCR Committee (21 December 2009), UN Doc E/C.12/GC/21 (2009) E.6.

49 General Comment 19: The right to social security, CESCR Committee (4 February 2008), UN Doc E/C.12/GC/19 (2008).

50 General Comment 18 on the the right to work, CESCR Committee (6 February 2006), UN Doc E/C.12/GC/18 (2006) 18. One year earlier, in General Comment 16 on the equal right of men and women to the enjoyment of all economic, social and cultural rights, CESCR Committee (13 May 2005), UN Doc E/C.12/2005/3 (2005) 10, the Committee had included migrant status in its non-discrimination statement but did not reference the Migrant Workers Convention.

51 Concluding Observations on the Combined Second and Third Periodic Reports of Tajikistan, CESCR Committee (25 March 2015), UN Doc E/C.12/TJK/CO/2-3 (2015) 22-24, 32 and 34. 
Vietnam, ${ }^{52}$ the Czech Republic, ${ }^{53}$ and Azerbaijan, ${ }_{55}^{54}$ and raised equal worker protection for irregular migrants with Japan. ${ }^{55}$

\subsubsection{Committee on the Elimination of Racial Discrimination}

The Committee on the Elimination of Racial Discrimination (CERD) monitors the International Convention on the Elimination of Racial Discrimination (ICERD), a 1966 treaty with 178 state parties, 57 of which have recognised CERD's competence to consider individual cases. In 2004, CERD issued General Recommendation 30 on discrimination against non-citizens, ${ }^{56}$ replacing an earlier General Recommendation that had excepted distinctions by a state on the basis of nationality from the definition of discrimination on the basis of article $1(2) .{ }^{57}$ This significant re-interpretation of its previous approach required that most measures taken against irregular migrants must be proportional to the achievement of a legitimate aim. ${ }^{58}$

Between 2013 and 2015, CERD did not make substantive reference to specific provisions of the Migrant Workers Convention when it considered migrants' rights in particular countries, but it did routinely call for ratification of the Convention. Notably, in multiple concluding observations, CERD stated that the country whose record was under examination, "bearing in mind the indivisibility of all human rights"59 should ratify the Migrant Workers Convention, 'which has direct relevance to racial discrimination' ${ }^{60}$

52 Concluding Observations on the Second to Fourth Periodic Report of Viet Nam, CESCR Committee (15 December 2014), UN Doc E/C.12/VNM/CO/2-4 (2014).

53 Concluding Observations on the Second Periodic Report of the Czech Republic, CESCR Committee (23 June 2014), UN Doc E/C.12/CZE/CO/2 (2014).

54 Concluding Observations on the Third Periodic Report of Azerbaijan, CESCR Committee (5 June 2013), UN Doc E/C.12/AZE/CO/3 (2013) 21.

55 Concluding Observations on the Third Periodic Report of Japan, CESCR Committee (10 June 2013), UN Doc E/C.12/JPN/CO/3 (2013) 21

56 General Recommendation 30, on discrimination against non-citizens, CERD Committee (Sixty-Fourth Session, 2004), UN Doc CERDC/64/Misc.11/rev.3 (2004). Differences of treatment based on citizenship or immigration status will constitute discrimination if the criteria for different treatment, judged in the light of the objectives and purposes of the Convention, are not applied in pursuit of a legitimate aim or are not proportional to its achievement (para 4).

57 See CERD Committee (n 56 above) para 39.

58 General Recommendation 11 on Non-Citizens, CERD Committee (Sixty-Second Session, 1994), UN Doc A/48/18 at 112 (1994).

59 See, eg, Concluding Observations on the Nineteenth to Twenty-First Periodic Reports of Cameroon, CERD Committee (26 September 2014), UN Doc CERD/C/CMR/ CO/19-21 (2014); Concluding Observations on the Combined Seventh to Ninth Periodic Reports of Japan, CERD Committee (26 September 2014), UN Doc CERD/ C/JPN/CO/7-9 (2014); Concluding Observations on the Combined Seventh to Ninth Periodic Reports of the United States of America, CERD Committee (25 September 2014), UN Doc CERD/C/USA/CO/7-9 (2014).

60 See, eg, Concluding Observations on the Combined Twentieth and Twenty-First Periodic Reports of Poland, CERD Committee (19 March 2014), UN Doc CERD/ C/ $\mathrm{POL} / \mathrm{CO} / 20-21$ (2014); Concluding Observations on the Combined Eighth and Ninth 
Of all the core treaty monitoring bodies other than the CMW, CERD was the most actively focused on migration issues during the two years under review. At the intersection of discrimination and migration, for example, CERD pressed for statistics-gathering on migrants (Cameroon, ${ }^{61}$ Japan, ${ }^{62}$ Kazakhstan, ${ }^{63}$ Luxembourg) ${ }^{64}$ action against racial profiling (United States), ${ }^{65}$ protection from discrimination in education, housing and employment against migrants (Poland, ${ }^{66}$ Cyprus), ${ }^{67}$ and curbing hate speech by politicians (Russian Federation). ${ }^{68}$ None of these countries has yet ratified the ICRMW, though one (Cameroon) has signed. ${ }^{69}$

\subsubsection{Committee on the Elimination of All Forms of Discrimination against Women}

Adopted in 1979, the Convention on the Elimination of All Forms of Discrimination against Women counts 189 ratifying nations, 109 of which have acceded to the individual complaints jurisdiction of the treaty's monitoring body, also known as the CEDAW. In the two years of Concluding Observations under review, the CEDAW rarely cited to treaties beyond its jurisdictional treaty, ${ }^{70}$ and did not cite to any substantive provisions of the ICRMW. It has, however, made many observations and recommendations relevant to the situation of migrant workers and their families. In reviewing gender concerns in state parties, the CEDAW has made observations and recommendations regarding a

Periodic Reports of Uzbekistan, CERD Committee (14 March 2014), UN Doc CERD/ C/UZB/CO/8-9 (2014); Concluding Observations on the Fourteenth and Seventeenth Periodic Reports of Luxembourg, CERD Committee (13 March 2014), CERD/C/LUX/CO/14-17 (2014); Concluding Observations on the Twentieth to the Twenty-Second Periodic Reports of the Russian Federation, CERD Committee (17 April 2013), UN Doc CERD/C/RUS/CO/20-22 (2013).

61 CERD Committee (n 59 above) 6

62 CERD Committee (n 59 above).

63 Concluding Observations on the Combined Sixth and Seventh Periodic Reports of Kazakhstan, CERD Committee (14 March 2014), UN Doc CERD/C/KAZ/CO/6-7 (2014) 16

64 CERD Committee (n 59 above) 6.

65 CERD Committee (n 59 above) 8,18

66 CERD Committee (n 60 above).

67 Concluding Observations on the Seventeenth to Twenty-Second Periodic Reports of Cyprus, CERD Committee 10 (23 September 2013), UN Doc CERD/C/CYP/CO/ 17-22 (2013).

68 CERD Committee (n 60 above) 12.

69 See United Nations Office of the High Commissioner for Human Rights 'Status of Ratification Interactive Dashboard' http://indicators.ohchr.org/ (accessed 31 July 2016)

70 The CEDAW made a general reference in one Concluding Observation: 'the Committee notes with concern the many discriminatory provisions in laws, such as the minimum age of marriage for girls in the Family Law ... which are contrary to the Convention and other international human rights instruments.' Concluding Observations on the Initial Report of Qatar, CEDAW Committee (9 March 2014), UN Doc CEDAW/C/ AT/CO/1 (2014) para 15 (2014 CEDAW Concluding Observations on Qatar) (emphasis added). 
number of issues concerning migrant women and girls. Amongst the Committee's concerns, for example, are health care (Greece, ${ }^{71}$ Qatar, ${ }^{72}$ Cambodia, ${ }^{73}$ Andorra, ${ }^{74}$ Dominican Republic),${ }^{75}$ including contraceptive services (Cyprus, ${ }^{76}$ Hungary), ${ }^{77}$ education (Greece, ${ }^{78}$ Finland, ${ }^{79}$ Denmark, ${ }^{80}$ Austria) ${ }^{81}$ and trafficking (Cyprus, ${ }^{82}$ Dominican Republic, ${ }^{83}$ Qatar, ${ }^{84}$ Cameroon, ${ }^{85}$ Lithuania, ${ }^{86}$ Poland). ${ }^{87}$ Of these Concluding Observations, two related to parties to the Migrant Workers Convention: Cambodia and Cameroon. ${ }^{88}$

Over the years CEDAW has also issued several General Recommendations touching on the rights of migrant women and girls. Most notably, in its 2008 General Recommendation 26 on women migrant workers, the Committee analyses the situation of women migrant workers and makes recommendations for protecting their human rights. It focuses on situations of trafficking but does not exclude the concerns of other women migrant workers. In paragraph two of General Recommendation 26, CEDAW makes an interesting statement about the ICRMW:

71 Concluding Observations on the Seventh Periodic Report of Greece Adopted by the Committee at its Fifty Fourth Session, CEDAW Committee (26 March 2013), UN Doc CEDAW/C/GRC/CO/7 (2013) 32-33.

722014 CEDAW Concluding Observations on Qatar (n 70 above) para 48.

73 Concluding Observations on the Combined Fourth and Fifth Periodic Reports of Cambodia, CEDAW Committee (28 October 2013), UN Doc CEDAW/C/ KHM/ CO/4-5 (2013) 38.

74 Concluding Observations on the Combined Second and Third Periodic Reports of Andorra, CEDAW Committee (27 October 2013), UN Doc CEDAW/C/AND/CO/ 2-3 (2013) 31-32.

75 Concluding Observations on the Combined Sixth and Seventh Periodic Reports of the Dominican Republic, CEDAW Committee (30 July 2013), UN Doc CEDAW/C/ DOM/CO/6-7 (2013) 37.

76 Concluding Observations on the Combined Sixth and Seventh Periodic Reports of Cyprus, CEDAW Committee (1 March 2013), UN Doc CEDAW/C/CYP/CO/6-7 (2013) 29-30.

77 Concluding Observations on the Combined Seventh and Eight Periodic Reports of Hungary, CEDAW Committee (26 March 2013), UN Doc CEDAW/C/HUN/CO/78 (2013) 31.

78 CEDAW Committee (n 71 above) 26-27.

79 Concluding Observations on the Seventh Periodic Report of Finland, CEDAW Committee (9 March 2014), UN Doc CEDAW/C/FIN/CO/7 (2014) 31.

80 Concluding Observations on the Eighth Periodic Report of Denmark, CEDAW Committee (10 March 2015), UN Doc CEDAW/C/DNK/CO/8 (2015) 34.

81 Concluding Observations on the Seventh and Eighth Periodic Reports of Austria CEDAW Committee (22 March 2013), UN Doc CEDAW/C/AUT/CO/7-8 (2013) 33.

82 CEDAW Committee (n 76 above) 19-20.

83 CEDAW Committee (n 75 above) 26.

84 CEDAW Committee (n 70 above) 26.

85 Concluding Observations on the Combined Fourth and Fifth Periodic Reports of Cameroon, CEDAW Committee (9 March 2014), UN Doc CEDAW/C/CMR/CO/45 (2014) 20-21.

86 Concluding Observations on the Fifth Periodic Report of Lithuania, CEDAW Committee (24 July 2014), UN Doc CEDAW/C/LTU/CO/5 (2014) 27.

87 Concluding Observations on the Combined Seventh and Eighth Periodic Report of Poland, CEDAW Committee (14 November 2014), UN Doc CEDAW/C/ POL/CO/ 7-8 (2014) 27.

88 See Status of Ratification Interactive Dashboard (n 69 above). 
This general recommendation intends to contribute to the fulfilment of the obligations of States parties to respect, protect and fulfil the human rights of women migrant workers, alongside the legal obligations contained in other treaties, the commitments made under the plans of action of world conferences and the important work of migration-focused treaty bodies, especially the Committee on the Protection of the Rights of All Migrant Workers and Members of their Families. While the Committee notes that the International Convention on the Protection of the Rights of All Migrant Workers and Members of Their Families protects individuals, including migrant women, on the basis of their migration status, the Convention on the Elimination of All Forms of Discrimination against Women protects all women, including migrant women, against sex- and gender-based discrimination. ${ }^{89}$

Given that article 7 of the Migrant Workers Convention ensures the rights of the Convention shall be observed without discrimination on the basis of sex, there is evidently overlap between the ICRMW and General Recommendation 26. Indeed, the General Recommendation concludes with a statement encouraging state parties

to ratify all international instruments relevant to the protection of the human rights of migrant women workers, in particular, the International Convention on the Protection of the Rights of All Migrant Workers and Members of Their Families. ${ }^{90}$

\subsubsection{Committee on the Rights of the Child}

The 1989 Convention on the Rights of the Child is the most widely ratified of the ten principal human rights treaties, with 196 state parties and 34 subject to the individual complaints jurisdiction of the CRC. Article 22 of the Convention requires that refugee and unaccompanied children shall receive appropriate protection and humanitarian assistance in the enjoyment of applicable rights set forth in the present Convention and in other international human rights or humanitarian instruments to which the said States are Parties. ${ }^{91}$

In 2005, the Committee on the Rights of the Child issued General Comment 6 on Treatment of Unaccompanied and Separated Children Outside their Country of Origin in which the Committee affirmed that 'the rights stipulated in the Convention apply to all children, including migrant children'. 92

89 General Recommendation 26 on Women Migrant Workers, CEDAW Committee (5 December 2008), UN Doc CEDAW/C/2009/WP.1/R (2008) 9.

90 CEDAW Committee (n 89 above) 29.

91 CRC (n 1 above) art 22.

92 General Comment 6: Treatment of Unaccompanied and Separated Children Outside Their Country of Origin CRC Committee (1 September 2005), UN Doc CRC/GC/ 2005/6 (2005). 
In recent years, the Committee has not cited to substantive provisions of the Migrant Workers Convention, but it has shown consistent concern for the situation of migrant children. Amongst other actions, the Committee has recommended that state parties keep statistics on migrant children (China, ${ }^{93}$ Kuwait, $^{94}$ Russian Federation, ${ }^{95}$ Portugal, $^{96}$ Paraguay), ${ }^{97}$ register the birth of the children of migrants (China), ${ }^{98}$ and ensure that governments take measures to secure maintenance from parents working abroad (Saint Lucia). ${ }^{99}$ Of the states to have received these recommendations, only Paraguay is a party to the ICRMW. ${ }^{100}$

\subsubsection{Committee against Torture}

The Committee against Torture (CAT) monitors the Convention against Torture and Other Cruel, Inhuman or Degrading Treatment or Punishment, a 1984 treaty with 162 state parties, 83 of which have accepted the Committee's competence to consider individual complaints. The Convention against Torture contains a critically important provision for migrants, stating in article 3 that no country may deport a migrant - 'a person' - to a country where he or she would face torture. On the basis of this mandate, CAT takes a direct interest in and hears frequent individual complaints regarding due process in deportation, and individual deportation and extradition decisions. In the two years under review, CAT made no substantive reference to the ICRMW, but did urge state party attention to many torture-related migration issues, such as training of officials who enforce immigration laws (Cyprus, ${ }^{101}$ Lithuania, ${ }^{102}$

93 Concluding Observations on the Combined Third and Fourth Periodic Reports of China, CRC Committee (29 October 2013), UN Doc CRC/C/CHN/CO-3-4 (2013) 18 .

94 Concluding Observations on the Second Periodic Report of Kuwait, CRC Committee (29 October 2013), UN Doc CRC/C/KWT/CO/2 (2013) 18.

95 Concluding Observations on the Report Submitted by the Russian Federation under Article 8, Paragraph 1, of the Optional Protocol to the Convention on the Rights of the Child on the Involvement of Children in Armed Conflict, CRC Committee (25 February 2014), UN Doc CRC/C/OPAC/RUS/CO/1 (2014).

96 Concluding Observations on the Report Submitted by Portugal under Article 8 , Paragraph 1, of the Optional Protocol to the Convention on the Rights of the Child on the Involvement of Children in Armed Conflict, CRC Committee (24 February 2014), UN Doc CRC/C/OPAC/PRT/CO/1 (2014).

97 Concluding Observations on the Initial Report of Paraguay Submitted by Portugal under Article 8, Paragraph 1, of the Optional Protocol to the Convention on the Rights of the Child on the Involvement of Children in Armed Conflict, CRC Committee (25 October 2013), UN Doc CRC/C/OPAC/PRY/CO/1 (2013) 12-13.

98 CRC Committee (n 93 above) 39-40.

99 Concluding Observations on the Combined Second to Fourth Periodic Reports of Saint Lucia, CRC Committee (8 July 2014), UN Doc CRC/C/LCA/CO/2-4 (2014).

100 See Status of Ratification Interactive Dashboard (n 69 above)

101 Concluding Observations on the Fourth Report of Cyprus, CAT Committee (16 June 2014), UN Doc CAT/C/CYP/CO/4 (2014) 11.

102 Concluding Observations on the Third Periodic Report of Lithuania, CAT Committee (17 June 2014), CAT/C/LTU/CO/3 (2014) 18. 
Poland $^{103}$ and Ukraine) ${ }^{104}$ and detention policies (Australia, ${ }^{105}$ Croatia, ${ }^{106}$ Lithuania, ${ }^{107}$ Thailand ${ }^{108}$ and the United States of America). 109

\subsubsection{Committee on the Rights of Persons with Disabilities}

Since it was adopted by the UN General Assembly in 2006, the Convention on the Rights of Persons with Disabilities has garnered 174 ratifications, including 91 declarations recognising its Committee's jurisdiction over individual complaints. ${ }^{110}$ In the two years under review, the Committee made no reference to the ICRMW nor spoke on migration issues.

\subsubsection{Committee on Enforced Disappearances}

The International Convention for the Protection of All Persons from Enforced Disappearance counts 57 ratifications and 21 acceptances of individual jurisdiction since its adoption by the General Assembly in 2006. The Committee on Enforced Disappearances has made no reference to the ICRMW, but in recent years has raised several concerns relating to migration. Amongst its recommendations are the need for training of migration officials (the Netherlands, ${ }^{111}$ Mexico) ${ }^{112}$ the need for due process in deportation (Spain), ${ }^{113}$ and to ensure the return of migrants' remains to their home countries when they die abroad (Mexico). ${ }^{114}$

103 Concluding Observations on the Combined Fifth and Sixth Periodic Reports of Poland, CAT Committee (23 December 2013), UN Doc CAT/C/POL/CO/5-6 (2013) 14.

104 Concluding Observations on the Sixth Periodic Report of Ukraine, CRC Committee (12 December 2014), UN Doc CAT/C/UKR/CO/6 (2014).

105 Concluding Observations on the Combined Fourth and Fifth Periodic Reports of Australia, CAT Committee (23 December 2014), UN Doc CAT/C/AUS/CO/4-5 (2014).

106 Concluding Observations on the Combined Fourth and Fifth Periodic Reports of Croatia, CAT Committee (18 December 2014), UN Doc CAT/C/HRV/CO/4-5 (2014).

107 CAT Committee (n 102 above), 17.

108 Concluding Observations on the Initial Report of Thailand, CAT Committee (20 June 2014), UN Doc CAT/C/THA/CO/1 (2014).

109 Concluding Observations on the Combined Third to Fifth Periodic Reports of the United States of America, CAT Committee (19 December 2014), UN Doc CAT/C/ USA/CO/3-5 (2014).

110 Though adopted by the UN General Assembly on 13 December 2006, the Convention was not opened for signature until 30 March 2007

111 Concluding Observations on the Report Submitted by the Netherlands under Article 29, Paragraph 1 of the Convention, CED Convention (10 April 2014), UN Doc CED/ $\mathrm{C} / \mathrm{NLD} / \mathrm{CO} / 1$ (2014).

112 Consideration of Reports Submitted by States Parties under Article 29, Paragraph 1, of the Convention, CED Convention (17 April 2014), UN Doc CED/C/MEX/1 (2014).

113 Concluding Observations on the Report Submitted by Spain under Article 29 Paragraph 1, of the Convention, CED Convention (12 December 2013), UN Doc CED/C/ESP/CO/1 (2013).

114 CPED Convention (n 1 above) 


\subsection{Additional monitoring bodies}

\subsubsection{Special Rapporteur on the human rights of migrants}

In 1999, the UN Commission on Human Rights established the mandate of the Special Rapporteur on the human rights of migrants. ${ }^{115}$ Of all the special mechanisms, the Special Rapporteur's mandate is most closely aligned with the Migrant Workers Convention. ${ }^{116}$ The mandate was proposed in 1998 by an expert working group, mandated by the Commission on Human Rights to report on the human rights of migrants. The Working Group took vulnerability as its criterion. It recommended the creation of 'an international mechanism to deal with human rights issues affecting different groups of migrants'. The Working Group noted the 'lack of a consistent and focused approach to a vulnerable group', and that several important migrant groups, including certain categories of migrant workers, remained outside the scope of the ICRMW. Moreover, 'all the indications are that there will be additional delay before the Convention, and thus its monitoring mechanism, becomes operational'. 117

The mandate was thus envisioned as complementary to the work of the treaty bodies, including the future CMW. The Special Rapporteur's mandate requires its holder to examine ways and means to overcome the obstacles existing to the full and effective protection of the human rights of this vulnerable group, and sets out four main functions: to 'request and receive' information on rights violations; to make recommendations to prevent and remedy violations; to promote the 'effective application' of relevant international norms; and to recommend actions at the national and international levels to eliminate violations of migrants' rights. ${ }^{118}$

115 The Commission on Human Rights (HRC) Resolution 1999/44; since then, the mandate of the Special Rapporteur has been extended by Commission on Human Rights Resolutions 2002/62 and 2005/47 and Human Rights Council resolutions 8/ $10,17 / 12$ and 26/19. As the UN website notes: 'The mandate of the Special Rapporteur covers all countries, irrespective of whether a State has ratified the International Convention on the Protection of the Rights of All Migrant Workers and Members of Their Families, of 18 December 1990.' OHCHR, 'Special Rapporteur on the human rights of migrants' http://www.ohchr.org/EN/Issues/Migration/ SRMigrants/Pages/SRMigrantsIndex.aspx (accessed 18 December 2015).

116 See T Lesser 'The role of United Nations special procedures in protecting the human rights of migrants' (2009) 28 Refugee Survey Quarterly 139.

117 Reports of the Inter Governmental Working Group of Experts on the Human Rights of Migrants, UNCHR (10 March 1998), UN Doc E/CN.4/1998/76 (1998) para 48; Specific Groups and Individuals, Migrant Workers, Repot of the Special Rapporteur, Ms Gabriela Rodri?guez Pizarro, UNCHR (27 December 2004), UN Doc E/CN.4/ 2005/85 (2004) paras 123-24. See E/CN.4/1999/80 (n 12 above) para 123.

118 For the full text, see HRC Resolution 1999/44 (n 115 above) para 3. 
The Special Rapporteur was also invited

within the framework of the Universal Declaration of Human Rights and all other international instruments, to request, receive and exchange information on violations of the human rights of migrants from Governments, treaty bodies ... special rapporteurs for various human rights questions ... and to respond effectively to such information.

The current mandate requests the Special Rapporteur 'to take into consideration relevant human rights instruments of the United Nations to promote and protect the human rights of migrants'. ${ }^{119}$

Thus the Convention is not specifically referred to in the mandate, except as a 'relevant human rights instrument', although there is indirect reference to the Committee on Migrant Workers as one of the treaty bodies. The mandate holder during the period under review, François Crépeau, did not see this as a limitation to discussion that the Convention can play a wider role. For example, noting the absence of any UN migration agency, and that IOM remained outside the UN, the 2015 Crépeau report commented that in order to 'include' IOM in the United Nations, it would amongst other measures,

need to be given a legal protection mandate and guided by the core international human treaties, including the International Convention on the Protection of the Rights of All Migrant Workers and Members of Their Families. ${ }^{120}$

\subsection{Support for Ratification}

\subsubsection{High Commissioner for Human Rights and the Office of the High Commissioner for Human Rights}

The High Commissioner for Human Rights and the Office of the High Commissioner for Human Rights, whose mandate covers the full range of human rights, ${ }^{121}$ have supported the Convention, urging states to ratify. Speaking on International Migrants Day in 2011, High Commissioner Navi Pillay said:

More than 20 years ago, States recognized that migrants needed specific protection and brought the Convention into existence ... it is high time that these same States now unblock the political will to ratify and effectively implement this important treaty.

119 CHR Resolution 1999/44 (n 115 above) para 5; Resolution 26/19 paras 2 \& 3

1202013 Crépeau Report (n 8 above) para 112.

121 See High Commissioner for the Promotion and Protection of All Human Rights, GA (20 December 1993), UN Doc A/RES/48/141 (1993), see 4(a) (including in the High Commissioner's mandate, '[t]o promote and protect the effective enjoyment by all of all civil, cultural, economic, political and social rights'). 
In her speech, she noted that the Convention made clear 'the link between migration and human rights', recognised the 'specific vulnerabilities of migrant workers' and offered 'guidance on national migration policies'. ${ }^{122}$

The Office's 2012-2013 Management Plan named migration as one of its six Strategic Priorities, and pledged to strengthen partnerships and outreach activities towards ratification of the Convention, 'including through its multiple presences at regional and national levels'. To this end, the Office would 'continue to engage with governments, parliamentarians, trade unions and civil society actors', and the High Commissioner would raise the issue of ratification of the Convention during country visits and in relevant international fora. ${ }^{123}$

OHCHR's 2014 report 'The Economic, Social and Cultural Rights of Migrants in an Irregular Status' referred repeatedly to the Convention's importance as both a normative instrument and as a guide for national migration policy making; the report drew attention to the value of Part VI as 'explicitly' providing 'a framework for human rights-based policymaking on migration':

For instance, State parties are enjoined to maintain appropriate services to deal with questions about international migration of workers and members of their families and formulate and implement policies on migration, exchange information with other State parties, provide information to employers and workers on policies, laws and regulations, and provide information and appropriate assistance to migrant workers and members of their families (art $65)$.

\subsubsection{UN Human Rights Council Universal Periodic Review}

The UN General Assembly established the Human Rights Council, and the Council's UPR, in 2006. The Human Rights Council is the UN's governmental forum for human rights, and the successor to the Commission on Human Rights. The UPR is an innovative process created to ensure a public government-to-government review of human rights. In the UPR cycle, the UPR Working Group solicits three written reports, one from the government whose performance is under review, and two from the Office of the High Commissioner for Human Rights, one reflecting input from UN agencies and the other reflecting civil society comments. Following a series of civil society-driven sessions, the Working Group holds a dialogue in which any country may put questions to

122 UN Human Rights, Office of the High Commissioner 'Human rights are not a matter of charity' (20 December 2011) http://www.ohchr.org/EN/NewsEvents/Pages/ HRAreNotMatterOfCharity.aspx (accessed 13 October 2016).

123 OHCHR Management Plan 2012-2013: Working for Results, 'Migration' http://www 2.ohchr.org/english/ohchrreport2011/web_version/media/pdf/9_Migration.pdf (accessed 13 October 2016). 
In her speech, she noted that the Convention made clear 'the link between migration and human rights', recognised the 'specific vulnerabilities of migrant workers' and offered 'guidance on national migration policies'. ${ }^{122}$

The Office's 2012-2013 Management Plan named migration as one of its six Strategic Priorities, and pledged to strengthen partnerships and outreach activities towards ratification of the Convention, 'including through its multiple presences at regional and national levels'. To this end, the Office would 'continue to engage with governments, parliamentarians, trade unions and civil society actors', and the High Commissioner would raise the issue of ratification of the Convention during country visits and in relevant international fora. ${ }^{123}$

OHCHR's 2014 report 'The Economic, Social and Cultural Rights of Migrants in an Irregular Status' referred repeatedly to the Convention's importance as both a normative instrument and as a guide for national migration policy making; the report drew attention to the value of Part VI as 'explicitly' providing 'a framework for human rights-based policymaking on migration':

For instance, State parties are enjoined to maintain appropriate services to deal with questions about international migration of workers and members of their families and formulate and implement policies on migration, exchange information with other State parties, provide information to employers and workers on policies, laws and regulations, and provide information and appropriate assistance to migrant workers and members of their families (art $65)$.

\subsubsection{UN Human Rights Council Universal Periodic Review}

The UN General Assembly established the Human Rights Council, and the Council's UPR, in 2006. The Human Rights Council is the UN's governmental forum for human rights, and the successor to the Commission on Human Rights. The UPR is an innovative process created to ensure a public government-to-government review of human rights. In the UPR cycle, the UPR Working Group solicits three written reports, one from the government whose performance is under review, and two from the Office of the High Commissioner for Human Rights, one reflecting input from UN agencies and the other reflecting civil society comments. Following a series of civil society-driven sessions, the Working Group holds a dialogue in which any country may put questions to

122 UN Human Rights, Office of the High Commissioner 'Human rights are not a matter of charity' (20 December 2011) http://www.ohchr.org/EN/NewsEvents/Pages/ HRAreNotMatterOfCharity.aspx (accessed 13 October 2016).

123 OHCHR Management Plan 2012-2013: Working for Results, 'Migration' http://www 2.ohchr.org/english/ohchrreport2011/web_version/media/pdf/9_Migration.pdf (accessed 13 October 2016). 
representatives of the country under review. The Working Group then generates a report containing a record of the dialogue and a series of recommendations, each ascribed to the country that generated it. The country under review may choose to accept or to 'note' (reject) each recommendation in a voluntary inter-sessional communication, and is expected to provide an update on implementation of the recommendations in the ensuing cycles of the UPR.

Since 2008, the year the UPR's processes began, most countries have been through the review cycle twice. As the process unfolds, the UPR is proving to be a site of significant advocacy for the Convention. ${ }^{124}$ Of the countries that have not ratified the Convention, virtually every one to pass through the UPR has received one or more written recommendations to ratify, and many have been questioned about the Convention during the live dialogue. The countries most routinely pressing other states to ratify are Ecuador, the Philippines, Mexico, Indonesia, and Turkey, but at least 43 countries have made these recommendations, most but not all of which are ICRMW state parties or signatories. ${ }^{125}$ These recommendations reflect an unprecedented level of public pressure on non-ratifying countries, not only to accede to the treaty, but also to give and justify their reasons for failing to do so. To date, wealthy countries frequently reject any ICRMW ratification recommendation without further explanation. If a justification for non-ratification is provided, countries typically assert that their domestic laws already provide - or improve upon - the Convention's protections. ${ }^{126}$ Less frequently, governments reject recommendations that

124 See A Desmond 'The triangle that could square the circle? The UN International Convention on the Protection of the Rights of All Migrant Workers and Members of Their Families, the EU and the Universal Periodic Review' (2015) 17 European Journal of Migration and Law 36. Discussion of the UPR was omitted from the previous portion of the article because the authors did not encounter instances of substantive crossreferencing to the ICRMW, even though concerns relating to migration frequently arise in UPR proceedings.

125 Albania, Algeria, Argentina, Azerbaijan, Bangladesh, Belarus, Bolivia, Burkina Faso, Cambodia, Cape Verde, Central African Republic, Chad, Chile, Cuba, Democratic Republic of Congo, Ecuador, Egypt, Ethiopia, Ghana, Guatemala, Honduras, Indonesia, Iran, Kyrgyzstan, Mali, Mexico, Morocco, Nicaragua, Nigeria, Pakistan, Paraguay, Peru, Philippines, Rwanda, Senegal, Sierra Leone, Sri Lanka, Sudan, Tajikistan, Trinidad \& Tobago, Turkey, Uganda, and Uruguay. See Status of Ratification Interactive Dashboard (n 69 above).

126 For recent examples, see Report of the Human Rights Council on its Eighth Session, Vice-President and Rapporteur: Mr Alejandro Artucio, HRC Council (1 September 2008), UN Doc A/HRC/8/52 (2008) paras 314, 606, 877, 961, documenting various country rejections in 2008: inland ('rejects recommendation to ratify ICRMW because existing national and European law already conforms with basic rights of migrants'); Czech Republic ('does not consider signing the ICRMW because of existing national and international protections for migrants'); Ukraine ('rejected recommendation by Mexico to ratify ICRMW because of existing and proposed national laws and European law on migrant rights') and Romania ('because existing national and European law already protects migrants'). 
they ratify the Convention on the ground that the treaty conflicts with their domestic regimes. ${ }^{127}$

\subsubsection{Treaty bodies}

As the review of their work has shown, although they make very little substantive reference to the Migrant Workers Convention, the human rights treaty monitoring bodies do actively advocate its ratification. During the two years under review, of the nine principal monitoring bodies apart from the CMW, one - the HRC - congratulated several state parties on having ratified the Migrant Workers Convention. ${ }^{128}$ Another six monitoring bodies went further, recommending ratification of the Convention in their concluding observations. For example, in recent years the Committee on ESCR urged 16 of the state parties whose records it reviewed to ratify the ICRMW (Finland, ${ }^{129}$ Slovenia, ${ }^{130}$ Nepal, ${ }^{131}$ Serbia, ${ }^{132}$ Uzbekistan, ${ }^{133}$ Denmark, ${ }^{134}$ Austria, ${ }^{135}$ Kuwait, ${ }^{136}$ Belgium, ${ }^{137}$

127 Artucio (n 126 above) para 775 (rejecting recommendation to ratify ICRMW 'because of conflict with domestic laws'); Andorra's 2010 statement in Report of the Working Group on the Universal Periodic Review Andorra: Addendum, Secretariat of the Human Rights Council (Sixteenth Session, 2011) UN Doc A/HRC/16/8/Add.1 (2011) 4 (rejecting ratification of ICRMW because, 'despite great overlap with current national legal protections, Andorran law does not provide for any other categories of migrant workers (eg frontier or temporary workers) to benefit from the same rights as legally residing or Andorran workers').

128 See Concluding Observations on Belize in the Absence of a Report, CCPR Committee (26 April 2013), UN Doc CCPR/C/BLZ/CO/1 (2013) 5(b) (Belize); Concluding Observations on the Third Periodic Report of the Plurinational State of Bolivia, CCPR Committee (6 December 2013), UN Doc CCPR/C/BOL/CO/3 (2013) 4(d) (Bolivia); Concluding Observations on the Initial Report of Indonesia (21 August 2013), UN Doc CCPR/C/IDN/CO/1 (2013) 4(a) (Indonesia); Concluding Observations on the Second Periodic Report of Kyrgyzstan, CCPR Committee (23 April 2014), UN Doc $\mathrm{CPR} / \mathrm{C} / \mathrm{KGZ} / \mathrm{CO} / 2$ (2014), B(d) (Kyrgyzstan); Concluding Observations on the Initial Report of Mauritania, CCPR Committee (21 November 2013), UN Doc CCPR/C/MRT/CO/1 (2013) 3(a) (Mauritania); Concluding Observations on the Initial Report of Mozambique, CCPR Committee (19 November 2013), UN Doc CCPR/C/MOZ/CO/1 (2013) 4 (Mozambique).

129 Concluding Observations on the Sixth Periodic Report of Finland, CESCR Committee (17 December 2014), UN Doc E/C.12/FIN/CO/6 (2014) 31.

130 Concluding Observations on the Second Periodic Report of Slovenia, CESCR Committee (15 December 2014), UN Doc E/C.12/SVN/CO/2 (2014) 31.

131 Concluding Observations on the Third Periodic Report of Nepal, CESCR Committee (12 December 2014), UN Doc E/C.12/NPL/CO/3 (2014) 30.

132 Concluding Observations on the Second Periodic Report of Serbia, CESCR Committee (10 July 2014), UN Doc E/C.12/SRB/CO/2 (2014) 37.

133 Concluding Observations on the Second Periodic Report of Uzbekistan, CESCR Committee (13 June 2014) UN), UN Doc E/C.12/UZB/CO/2 (2014) 29.

134 Concluding Observations on the Fifth Periodic Report of Denmark, CESCR Committee (6 June 2013), UN Doc E/C.12/DNK/CO/5 (2013) 25.

135 Concluding Observations on the Fourth Periodic Report of Austria, CESCR Committee (13 December 2013), UN Doc E/C.12/AUT/CO/4 (2013) 26.

136 Concluding Observations on the Second Periodic Report of Kuwait, CESCR Committee (19 December 2013), UN Doc E/C.12/KWT/CO/2 (2013) 17 (recommending accession to ICRMW).

137 Concluding Observations Concerning the Fourth Periodic Report of Belgium, CESCR Committee (23 December 2013), UN Doc E/C.12/BEL/CO/4 (2013) 26. 
Montenegro, ${ }^{138}$ Romania, ${ }^{139}$ Lithuania, ${ }^{140}$ Monaco, ${ }^{141}$ Belarus, ${ }^{142}$ Iran, ${ }^{143}$ Togo). ${ }^{144}$ The CERD $,{ }^{145} \mathrm{CRC},{ }^{146} \mathrm{CEDAW},{ }^{147}$ and $\mathrm{CAT}^{148}$ are similarly proactive, urging ratification upon most, though not all, of the non-ratifying countries that come before them.

138 Concluding Observations on the Initial Report of Montenegro, CESCR Committee (15 December 2014), UN Doc E/C.12/MNE/CO/1 (2014) 27.

139 Concluding Observations on the Combined Third to Fifth Periodic Reports of Romania, CESCR Committee (9 December 2014), UN Doc E/C.12/ROU/CO/3-5 (2014) 27

140 Concluding Observations on the Second Periodic Reports of Lithuania, CESCR Committee (24 June 2014), UN Doc E/C.12/LTU/CO/2 (2014) 28

141 Concluding Observations Concerning the Second and Third Periodic Reports of Monaco, submitted as a single document, CESCR Committee (19 June 2014), UN Doc E/C.12/MCO/CO/2-3 (2014) 27

142 Concluding Observations on the Combined Fourth to Sixth Periodic Reports of Belarus, CESCR Committee (13 December 2013), UN Doc E/C.12/BLR/CO/4-6 (2013) 32 .

143 Concluding Observations on the Second Periodic Report of the Islamic Republic of Iran, CESCR Committee (10 June 2013), UN Doc E/C.12/IRN/CO/2 (2013) 33.

144 Concluding Observations on the Initial Report of Togo, Adopted by the Committee at its Fiftieth Session, CESCR Committee (3 June 2013), UN Doc E/C.12/TGO/CO/1 (2013) 38 .

145 See, eg, Concluding Observations on the Nineteenth to Twenty-First Periodic Reports of Cameroon, CERD Committee (26 September 2014), UN Doc CERD/C/CMR/ CO/19-21 (2014) 20 (recommending Cameroon ratify the ICRMW); Concluding Observations on the Combined Nineteenth to Twenty-First Periodic Reports of Sweden, CERD Committee (23 September 2013), UN Doc CERD/C/SWE/CO/19. 21 (2013) 22, with Concluding Observations on the Sixteenth to Nineteenth Periodic Reports of Belgium, CERD Committee (14 March 2014), UN Doc CERD/C/BEL/ CO/16-19 (2014) (not urging ratification of the ICRMW, although Belgium is not yet a party to the ICRMW, and the document contains several concerns and recommendations relating to migrants).

146 See Concluding Observations on the Combined Third and Fourth Periodic Reports of China, CRC Committee (29 October 2013), UN Doc CRC/C/CHN/CO/3-4 (2013) 98; Concluding Observations on the Combined Third and Fourth Periodic Reports of Luxembourg, CRC Committee (29 October 2013), UN Doc CRC/C/LUX/CO/3-4 (2013) 52; with Concluding Observations on the Initial Report of China submitted under article 8 of the Optional Protocol to the Convention on the Rights of the Child on the involvement of children in armed conflict, CRC Committee (29 October 2013), UN Doc CRC/C/OPAC/CHN/CO/1 (2013) (not urging ratification of the ICRMW, although China is not yet a party to the ICRMW and the document discusses the importance of registering migrant children, a right protected in ICRMW article 29).

147 See, eg, Concluding Observations on the Combined Sixth and Seventh Periodic Reports of the Democratic Republic of the Congo, CEDAW Committee (30 July 2013), UN Doc CEDAW/C/COD/CO/6-7 (2013) 45; Concluding Observations on the Combined Sixth and Seventh Periodic Reports of the Dominican Republic CEDAW Committee (30 July 2013) UN Doc CEDAW/C/DOM/CO/6-7 (2013) 48, with Concluding Observations on the Seventh Periodic Report of the United Kingdom of Great Britain and Northern Ireland, CEDAW Committee (30 July 2013), UN Doc CEDAW/C/GBR/CO/7 (2013)(not urging ratification of the ICRMW, although the United Kingdom of Great Britain and Northern Ireland is not yet a party to the ICRMW and the document contains discussion of immigrant women (par 56)).C

148 See, eg, Concluding Observations on the Initial Report of the Holy See, CAT Committee (17 June 2014), UN Doc CAT/C/VAT/CO/1 (2014) Section C; Concluding Observations on the Combined Fourth and Fifth Periodic Reports of Australia, CAT Committee (23 December 2014), UN Doc CAT/C/AUS/CO/4-5 (2014) Section C; compare Concluding Observations on the Combined Third to Fifth Periodic Reports of the United States of America, CAT Committee (19 December 2014), UN Doc AT/C/USA/CO/3-5 (2014) (not urging ratification of the ICRMW, although the United States of America is not yet a party to the ICRMW and the document contains several recommendations concerning migrants (sec C)). 


\subsubsection{Special Rapporteurs}

As discussed above, while the Special Rapporteur on the human rights of migrants has described the Migrant Workers Convention as an instrument that overlaps with existing protections, he nevertheless recognises it as an important element in the migrant rights regime. In his recommendations to countries pursuant to country visits, the Special Rapporteur routinely urges non-state parties to ratify the Convention. For example, in a 2015 report on the management of Europe's external borders, he urged EU member states to 'reconsider' their 'general refusal' to ratify the ICRMW noted that their unwillingness to ratify the Convention 'reflects the intention to not be held accountable for human rights abuses against undocumented migrant workers'. 149

Another mechanism particularly relevant to migrants is the mandate of the Special Rapporteur on trafficking in persons, especially women and children. Although the ICRMW is not referred to in the Human Rights Council's resolution establishing the mandate, 150 on occasion the Special Rapporteur's reports do include calls for ratification of the Convention. ${ }^{151}$ For example, in 2010, the Special Rapporteur urged ratification of the Convention, stating ' $[\mathrm{t}]$ he protection of the human rights of migrants is of paramount importance in preventing exploitation that leads to trafficking'. ${ }^{152}$

\subsubsection{Recent processes around migration}

In 2006, the UN General Assembly convened a High-Level Dialogue on Migration and Development; that this was the first ever discussion of migration by the General Assembly demonstrates the unwillingness of states to undertake multilateral engagement with migration. This meeting led to bi-annual meetings of the Global Forum on Migration and

149 Report of the Special Rapporteur on the human rights of migrants, François Crépeau, 'Banking on mobility over a generation: Follow up to the regional study on the management of the external borders of the European Union and its impact on the human rights of migrants' HRC Council (8 May 2015), UN Doc A/HRC/29/36 (2015) paras 58 and 118. See also, for example, Report of the Special Rapporteur on the human rights of migrants: François Crépeau: Follow-up mission to Italy (2-6 December 2014), HRC Council (1 May 2015), UN Doc A/HRC/29/36/Add.2 (2015) Recommendation A.1(d); Report of the Special Rapporteur on the human rights of migrants, François Crépeau: Addendum: Mission to Malta (6-10 December 2014), HRC Council (12 May 2015), UN Doc A/HRC/29/36/Add. 3 (2015) Recommendation A(1)(c).

150 Mandate of the Special Rapporteur on trafficking in persons, especially women and children, Human Rights Council (17 July 2014), UN Doc A/HRC/RES/26/8 (2014).

151 Report of the Special Rapporteur on trafficking in persons, especially women and children, Joy Ngozi Ezeilo, GA (9 August 2010), UN Doc A/65/288 (2010) 68; Report of the Special Rapporteur on trafficking in persons, especially women and children, Joy Ngozi Ezeilo, Addendum, Mission to Italy, HRC Council (1 April 2014), UN Doc A/HRC/26/37/Add. 4 (2014)89(a).

152 Ezeilo (n 151 above) 68 . 
Development (GFMD), a 'voluntary, informal, government-led process open to all UN member states', but outside the UN. As of June 2017, ten GFMDs have taken place, punctuated by a second High-Level Dialogue in 2013. Each of these meetings featured country delegation deliberations and statements and included civil society participation. The reports summarising the earlier meetings reflect a pattern of strong support for ratification of the Convention on the part of civil society and 'a number of' country delegates. ${ }^{153}$ Statements in support of the treaty are generally followed by softening or demurral statements from 'other' delegates stressing alternative steps that should take priority over ratification, such as 'look[ing] at how countries implement migrants' rights in practice' ${ }^{154}$

At the 2010 GFMD, at least one delegate went even further, registering an oblique but unmistakable vote of no confidence for the Convention:

While some stressed the importance of states adopting existing treaties on protecting migrants, a view was expressed that there is a need to review UN conventions that have only been ratified by a few states. ${ }^{155}$

In 2011, the civil society delegates' statement included its strongest language in support of the Migrant Workers Convention:

Although there is little consensus as yet as to the form that global governance might take, civil society agrees that whatever system develops must have an indisputable basis in normative frameworks. Such norms exist in the UN Migrant Workers Convention - not an exception but rather one of the ... core international human rights treaties. The reticence of developed countries in particular to ratify the UN Migrant Workers Convention is disingenuous to their own often better traditions of appreciating rights, and unhelpful with respect to other countries that need to ratify and respect the Convention. ${ }^{156}$

More recently, governments favouring the Convention appear to have grown even more reticent in the GFMD context, while civil society actors continue their annual call for ratification. The Declaration of the 2013 High-Level Dialogue went so far as to

153 For example, Global Forum on Migration and Development First Meeting, Brussels, July 9-11, 2007: Summary Report, 16 ('a number of states'); Global Forum on Migration and Development, Third Meeting, Athens 2-5 November 2009: Integrating Migration Policies into Development Strategies for the Benefit of All: Report of the Proceedings, 27 ('a number of delegates').

154 Report of the Swedish Chairmanship of the Global Forum on Migration and Development 2013-2014: Unlocking the potential of migration for inclusive development, 46 (emphasis in original).

155 Fourth Meeting of the Global Forum on Migration and Development (GFMD): Puerto Vallarta, Mexico, 8-11 November 2010 'Partnerships for migration and human development: Shared prosperity - Shared responsibility' Report of the Proceedings, 17

156 Fifth Meeting of the Global Forum on Migration and Development (GFMD): GFMD 2011 Concluding Debate, Geneva, Switzerland: 1-2 December 2011 'Taking action on migration and development - Coherence, capacity and cooperation' Report of the Proceedings, 2. 
[n]ote the contribution of applicable international conventions, including the International Convention on the Protection of the Rights of All Migrant Workers and Members of Their Families, to the international system for the protection of migrants. ${ }^{157}$

This lukewarm endorsement contrasts with the statement in the same Declaration encouraging states to ratify 'relevant international instruments on preventing and combating trafficking in persons and smuggling of migrants'. ${ }^{158}$ In 2016, the report from the Millennium Summit reflected a call from the Secretary-General mentioning the ICRMW and calling generally for ratification. ${ }^{159}$ The final resolution of the UN General Assembly High Level Plenary on Addressing Large Movements of Refugees and Migrants called on states to 'consider ratifying or acceding to' the Convention. ${ }^{160}$

\section{Institutional interaction}

As the preceding description reflected, most direct references to the Migrant Workers Convention are supportive, with the Global North's negative attitudes manifesting themselves in more oblique ways. ${ }^{161}$ In spite of its slow ratification rate and low number of state parties, the Migrant Workers Convention functions institutionally much like the other human rights treaties. Administrative support for the CMW is comparable with that of other treaty monitoring bodies, although there would be incrementally more funding if the number of ratifications increased. However, it does not have the same level of agency support as, for example, the Committee on the Rights of the Child receives from UNICEF, although the ILO consistently participates in Committee deliberations. François Crépeau has floated the novel idea that IOM, now a related UN organisation, should act as a support agency, and 'institutional champion' to the ICRMW, with similar mutual benefits to those which flow from UNICEF's support for the Committee of the Rights of the Child. ${ }^{162}$

157 Declaration of the High-level Dialogue on International Migration and Development, GA (21 January 2014), UN Doc A/Res./68/4 15 (2014).

158 Declaration of the High-level Dialogue (n 157) 17.

159 Follow-up to the Outcome of the Millennium Summit 'In Safety and Dignity: Addressing Large Movements of Refugees and Migrants' Report of the SecretaryGeneral, GA (21 April 2016), UN Doc A/70/59 (2016) para 88.

$160 \mathrm{n} 159$ above, para 48

161 For analysis of government attitudes toward the Convention, see A Pécoud 'The politics of the UN Convention on Migrant Workers' Rights' in this volume.

162 Report of the Special Rapporteur on the human rights of migrants, GA (20 July 2016), UN Doc A/71/40767 (2016) para 120: 'This little ratified Convention would benefit from an institutional champion able to muster adhesion to its principles. Such a responsibility would contribute to strengthening the human rights culture within IOM and provide it with an appropriate normative tool to measure its action and to negotiate projects with states. IOM would thus complement the important work of the United Nations Committee on Migrant Workers, in the same way that UNICEF and 
A recent example of institutional interaction which is to be commended is the decision that a General Comment on child migrants is to be jointly authored by the Committee on the Rights of the Child and the CMW. This is a welcome development, and compares favourably with the CEDAW's sole authored 2008 General Recommendation on women migrant workers.

Like other human rights treaty monitoring bodies, the CMW is composed of individuals nominated by the ratifying countries. Each ICRMW state party may nominate one person for election 'from among its own nationals' 163 who is an expert 'of high moral standing, impartiality and recognized competence in the field covered by the Convention'.164 The Committee is the only treaty body composed exclusively of members from the Global South, which reflects the failure of northern states to ratify. 165

A 2012 report from the Geneva Academy of International Humanitarian Law and Human Rights highlights another aspect of the CMW's composition: the number of members with links to government. The report, entitled 'The Independence of UN Human Rights Treaty Body Members', examines the professional background of treaty body members. The report quotes the Addis Ababa Guidelines for the Independence and Impartiality of the Treaty Body Members, adopted at a meeting of treaty body leaders in 2012: '(t)he independence and impartiality of treaty body members is compromised by the political nature of their affiliation with the executive branch of the State. ${ }^{166}$

As with other treaty bodies, the CMW members are elected and serve 'in their personal capacity. ${ }^{167}$ However, the report documents that, as of 2012, the CMW had the highest percentage of members with an executive branch affiliation: 9 out of 14 members -64 per cent. ${ }^{168}$ The average for all human rights treaty bodies was 32 per cent, ${ }^{169}$ with the Human Rights Committee lowest at 5 per cent ${ }^{170}$ and the CEDAW Committee the

the Committee on the rights of the child are complementing each other in the implementation of the Convention on the rights of the child.'

163 ICRMW (n 1 above) art 72(2)(a).

164 ICRMW (n 1 above) art 72(1)(b).

165 V Chetail 'The Committee on the Protection of the Rights of All Migrant Workers and Members of Their Families' in P Alston \& F Megret (eds) The United Nations and human rights: A ccritical appraisal (forthcoming 2018). For an earlier article, see C Edelenbos 'Committee on Migrant Workers and implementation of the ICRMW' in $\mathrm{P}$ De Guchteneire et al (eds) Migration and human rights: The United Nations Convention on Migrant Workers' Rights (2009) 100-121.

166 Geneva Academy of International Humanitarian Law and Human Rights 'The independence of UN Human Rights treaty body members' (December 2012) 42 (Treaty Body Independence Report).

167 ICRMW (n 1 above) art 72(2)(b).

168 Treaty Body Independence Report (n 166 above) 23

169 Treaty Body Independence Report (n 166 above) 24.

170 Treaty Body Independence Report (n 166 above) 20 
second highest, with 52 per cent. ${ }^{171}$ Institutionally, monitoring of the Convention reflects some effects of the treaty's rejection by the Global North, with less agency support and a composition that skews toward government official participation.

The 2012 report did not speculate on the reasons why such a high number of CMW members came from the executive branches of their countries. One possible explanation is that treaty body members are unpaid, which is likely to have a number of indirect consequences, including making membership more financially feasible for those in government service, who can attend meetings in the course of their employment.

\section{Conclusion}

United Nations human rights experts and mechanisms widely and frequently acknowledge that the ICRMW provides the primary normative rights framework for migration. Frequently though not uniformly, UN mechanisms, the state parties to the Convention, and also non-state parties from the Global South, urge wider ratification of the treaty. All actors have been slower to embrace the treaty substantively, though here the Convention is likely to benefit from the increasing trend towards cross referencing of the core treaties, for example through the UPR and the use of joint general comments.

One recurring theme in the history of human rights law is the tension between national sovereignty and international standard-setting; this tension tends to increase where those in need of protection are not citizens. But, over time, states have generally recognised the value of international oversight systems. States increasingly accept oversight even of sensitive issues concerning migrants' rights under other, more widely ratified, human rights treaties. What were often presented as mutually exclusive treaty regimes, with the ICRMW being negatively contrasted with the other core treaties, tends now to be seen as positive, and as constituting in the words of the CMW - a 'complementary and mutually reinforcing' system of legal protections. With time the Committee is becoming better positioned to articulate and advocate a human rights approach to migration. Its work is increasingly needed to provide both individual protection and a comprehensive framework for rights-based policymaking, as migration is pushed to a higher place on the UN and multilateral agendas. 